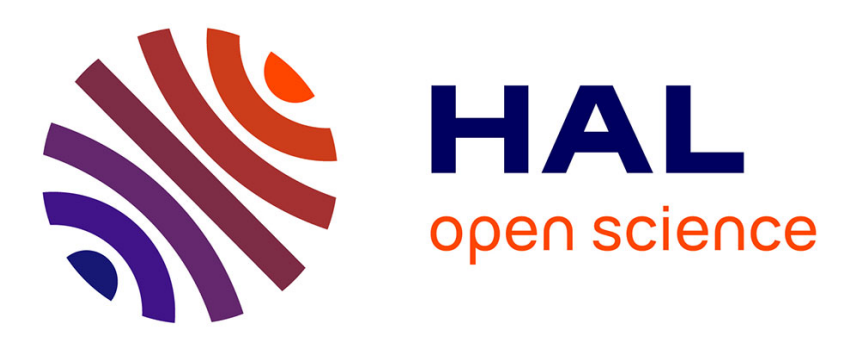

\title{
Electrochemical synthesis of 3a-bromofuranoindolines and 3a-bromopyrroloindolines mediated by $\mathrm{MgBr} 2$
}

Ju Wu, Hussein Abou-Hamdan, Régis Guillot, Cyrille Kouklovsky, Guillaume Vincent

\section{- To cite this version:}

Ju Wu, Hussein Abou-Hamdan, Régis Guillot, Cyrille Kouklovsky, Guillaume Vincent. Electrochemical synthesis of 3a-bromofuranoindolines and 3a-bromopyrroloindolines mediated by $\mathrm{MgBr} 2$. Chemical Communications, 2020, 56 (11), pp.1713-1716. 10.1039/C9CC09276E . hal-02960483

\section{HAL Id: hal-02960483 \\ https://hal.science/hal-02960483}

Submitted on 12 Nov 2020

HAL is a multi-disciplinary open access archive for the deposit and dissemination of scientific research documents, whether they are published or not. The documents may come from teaching and research institutions in France or abroad, or from public or private research centers.
L'archive ouverte pluridisciplinaire HAL, est destinée au dépôt et à la diffusion de documents scientifiques de niveau recherche, publiés ou non, émanant des établissements d'enseignement et de recherche français ou étrangers, des laboratoires publics ou privés. 


\title{
Electrochemical Synthesis of 3a-Bromofuranoindolines and 3a- Bromopyrroloindolines Mediated by $\mathrm{MgBr}_{2}$.
}

Received 00th January 20xx,

Accepted 00th January 20xx

DOI: $10.1039 / \times 0 \times x 00000 x$

\author{
Ju Wu, ${ }^{a}$ Hussein Abou-Hamdan, ${ }^{a}$ Régis Guillot, ${ }^{a}$ Cyrille Kouklovsky ${ }^{a}$ and Guillaume Vincent ${ }^{\text {a* }}$
}

\begin{abstract}
We report an efficient and environmentally friendly electrochemical approach to perform the bromo cyclization of tryptophol, tryptamine and tryptophan derivatives. The 3abromofuranoindolines and 3a-bromopyrroloindolines obtained are of interest in the total synthesis of natural products. This dearomative procedure relies on the generation of an electrophilic bromine reagent by the electrochemical oxidation of $\mathrm{MgBr}_{2}$. No organic byproducts are generated with this protocol which avoids the use of an additional electrolyte.
\end{abstract}

3a-Bromopyrroloindolines $\mathbf{1}$ are versatile building blocks in which the carbon-bromide bond could be involved in a substitution reaction with retention of configuration in order to form stereospecifically a new C-C, C-N or C-O bond yielding functionalized pyrroloindolines $\mathbf{2}$ via carbocation $\mathbf{A}$ or radical intermediate B. $^{1}$ Such approaches are widely deployed to access tryptophan-derived natural products as exemplified by the total syntheses of WIN 64821, pestalazine A, drimentine G, gliocladin $C$ or novoamaurimonine among others. ${ }^{2}$ 3aBromopyrroloindolines $\mathbf{1}$ are usually synthesized by the treatment of tryptophan derivatives $\mathbf{3}$ with a stoichiometric electrophilic bromine reagent such as NBS 4., ${ }^{1,2}$ Reaction with the nucleophilic C3 position of the indole nucleus allows to form 3a-bromopyrroloindolines 1.

More recently, bromides and others halides salts in combination with stoichiometric oxidants were also employed via the in-situ generation of electrophilic halogen reagents to achieve such transformations. ${ }^{3,4}$ In particular, the group of Tong, reported the combination of $\mathrm{KBr}$ and oxone to reduce the amount of organic wastes produced. ${ }^{4}$

In this context, we would like to report an electrochemical protocol for the dearomative halocyclization of tryptophol 5,

a. Institut de Chimie Moléculaire et des Matériaux d'Orsay (ICMMO)

Univ. Paris Sud, Université Paris-Saclay, CNRS

15 rue Georges Clémenceau, 91405 Orsay, Cedex, France

*guillaume.vincent@u-psud.fr

Electronic Supplementary Information (ESI) available: [details of any supplementary information available should be included here]. See DOI: 10.1039/x0xx00000x tryptamine and tryptophan derivatives 6 which avoids the use of an external oxidant and therefore the formation of organic wastes to form the corresponding 3a-bromofuranoindolines 7 and 3a-bromopyrroloindolines 8 (Scheme 2).

Scheme 1. Classical synthesis of 3a-bromopyrroloindolines and their importance in natural product synthesis.
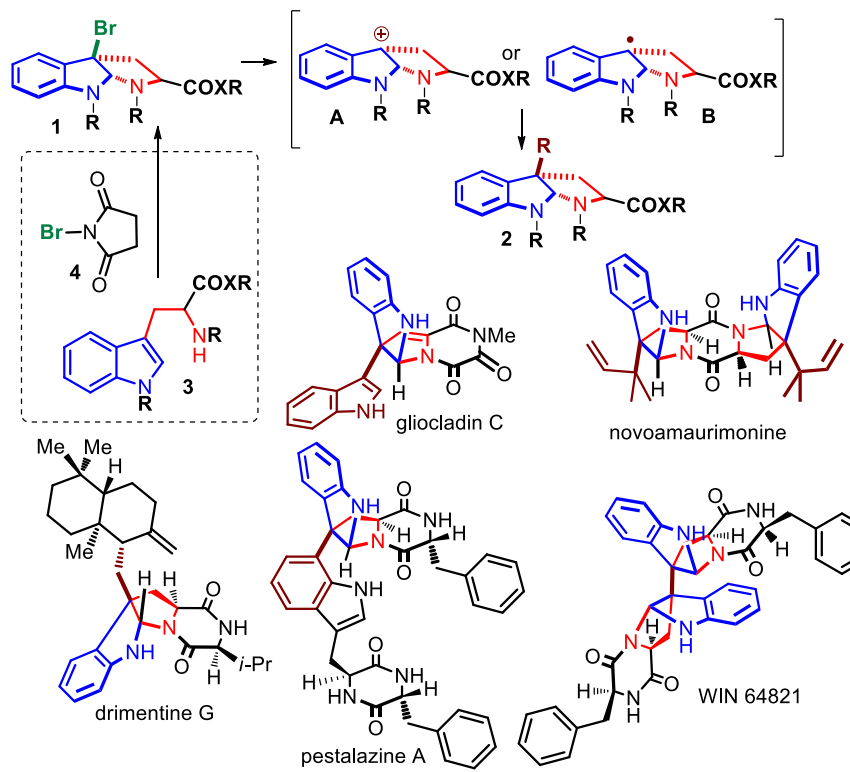

novoamaurimonine

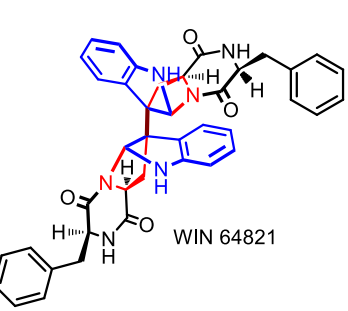

Scheme 2. Anodic oxidation of bromide salts for the bromocyclization of indoles.

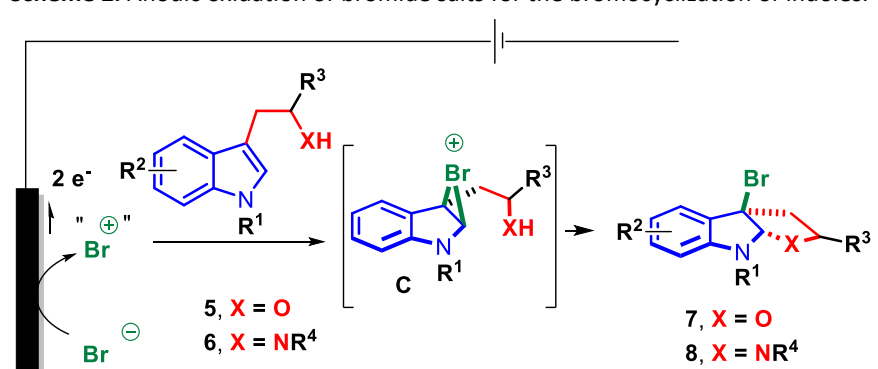


Electrochemistry is emerging as a powerful and sustainable tool $^{5}$ to achieve dearomatisation reactions of (hetero)arenes ${ }^{6}$ and in particular indoles. ${ }^{7}$

In line with our interest in the development of oxidative dearomatization reactions of indoles, ${ }^{8,9}$ we recently reported a general electrochemical dearomative dialkoxylation and diazidation of indoles. ${ }^{10}$ As in previous works, ${ }^{7 b, c, e}$ this reaction proceeds via the direct oxidation at the anode of the indole nucleus into a radical cation. In contrast, to achieve an electrochemical dearomative bromocyclization of 3-substituted indoles into 3a-bromopyrroloindolines, we planned to rely on the anodic oxidation of a bromide salt into an electrophilic specie that would be intercepted by the nucleophilic indole of 5 or $\mathbf{6}$ to form bromonium ion $\mathbf{C}$ which would be converted into $\mathbf{7}$ or $\mathbf{8}$ while protons would be reduced into $\mathrm{H}_{2}$ at the cathode.

Indeed, the electrochemical oxidation of halides is known and is a clean halogenation method for alkenes, alkynes or (hetero)arenes ${ }^{11}$ including indoles. ${ }^{12}$ However, in this study, we would like to deploy electrogenerated electrophilic halogen intermediates in dearomatization reactions (Scheme 2).

In addition to be the source of the electrophilic reagent, we expect that the bromide salt would also act as an electrolyte which would avoid the use of an additional electrolyte and therefore reduce the wastes of this process.

After an initial evaluation of different parameters (see SI), we identified that we could achieve the expected electrochemical transformation either in a galvanostatic mode with a constant current of $4.5 \mathrm{~mA} / \mathrm{cm}^{2}$ or in a potentiostatic mode with a constant cell potential of $5 \mathrm{~V}$. Both these set of conditions involved to perform the electrolysis in an undivided cell with a graphite anode and platinum-plated cathode in a 4:1 mixture of acetonitrile and water at room temperature. Among the bromide salts tested, we found out that it was optimal to use 1 equivalent of $\mathrm{MgBr}_{2}$ as source of bromide and as electrolyte.

We first studied the scope of the bromocyclisation of tryptophol derivatives $\mathbf{5}$ into bromofuranoindolines $\mathbf{7}$ (Scheme 3). Various protecting groups of the indole nitrogen such as Boc, acetyl and tosyl were successfully evaluated leading to $7 \mathbf{a}-\mathbf{c}$. It was also possible to operate at a constant potential of $3.5 \mathrm{~V}$ at the anode vs an $\mathrm{Ag} / \mathrm{AgCl}$ reference electrode instead of a constant potential between the anode and the cathode for 7c. Tryptophol derivatives bearing substituents on the benzene part of the indole led to the formation of 3abromofuranoindolines $\mathbf{7 d - f}$ whether a chloro or a donating group (methyl and methoxy) is present. Replacing $\mathrm{MgBr}_{2}$ by $\mathrm{MgCl}_{2}$ delivered the corresponding 3a-chlorofuranoindoline $\mathbf{7 g}$ albeit in a lower yield.

We then turned our attention towards the synthesis of 3abromopyrroloindolines from protected tryptamines (Scheme 4). In addition to $\mathrm{N}, \mathrm{N}^{\prime}$-diBoc bromopyrroloindoline $\mathbf{8 a}$, different combinations of orthogonal protecting groups of the indole and amine nitrogens were assessed. N-Boc, $\mathrm{N}^{\prime}-\mathrm{Cbz}$ and $\mathrm{N}-\mathrm{Boc}, \mathrm{N}^{\prime}$ $\mathrm{CO}_{2} \mathrm{Me}$ bromopyrroloindolines $\mathbf{8 b}, \mathbf{c}$ were thus obtained. A tosyl group could also be present on the indole nitrogen in combination with $\mathrm{Boc}, \mathrm{Cbz}$ and $\mathrm{CO}_{2} \mathrm{Me}$ protecting groups of the primary amine leading to compounds $\mathbf{8 d - f}$. Substitution of the

benzene part is tolerated as demonstrated with 6-bromo indolines $\mathbf{8 g}$-i and 5-methyl indoline $\mathbf{8 j}$.

Subsequently, we decided to evaluate the bromo-cyclization of diversely protected (L) and (D)-trytophan derivatives leading respectively to $\mathbf{8 k - m}$ and $\mathbf{8 n}, \mathbf{0}$. The cyclization proceeded with an exo selectivity as demonstrated by the $\mathrm{X}$-ray crystal structure of $8 n$.

Scheme 3. Electrochemical dearomative halocyclization of tryptophol derivatives.

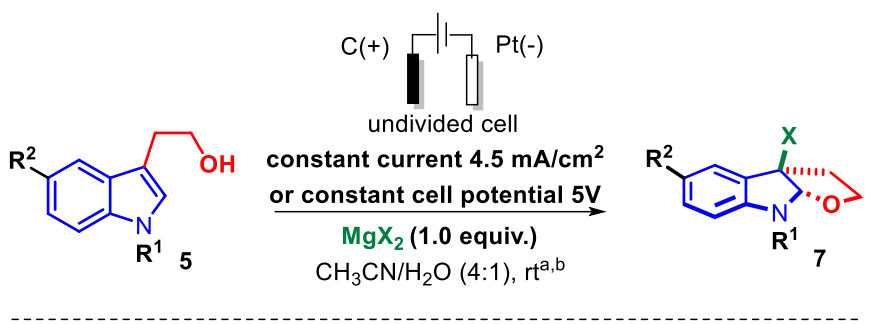

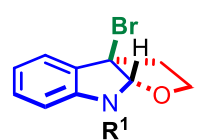

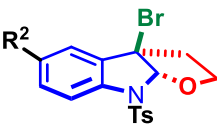

7d, $\mathbf{R}^{2}=\mathbf{C l}, 72 \%\left(4.5 \mathrm{~mA} / \mathrm{cm}^{2}\right), 62 \%(5 \mathrm{~V})$

7e, $\mathbf{R}^{2}=\mathbf{M e}, 63 \%\left(4.5 \mathrm{~mA} / \mathrm{cm}^{2}\right), 59 \%(5 \mathrm{~V})$

7f, $\mathbf{R}^{2}=$ OMe, $73 \%\left(4.5 \mathrm{~mA} / \mathrm{cm}^{2}\right), 83 \%(5 \mathrm{~V})$ 7a, $\mathbf{R}^{\mathbf{1}}=$ Boc, $80 \%\left(4.5 \mathrm{~mA} / \mathrm{cm}^{2}\right), 75 \%(5 \mathrm{~V})$

7b, $\mathbf{R}^{1}=\mathbf{A c}, 80 \%\left(4.5 \mathrm{~mA} / \mathrm{cm}^{2}\right), 69 \%(5 \mathrm{~V})$

7c, $\mathbf{R}^{\mathbf{1}}=\mathbf{T s}, 90 \%\left(4.5 \mathrm{~mA} / \mathrm{cm}^{2}\right)$ $93 \%(5 \mathrm{~V}), 93 \%(3.5 \mathrm{~V} \text { vs } \mathrm{Ag} / \mathrm{AgCl})^{\mathrm{c}}$

a) Undivided cell, graphite-SK50 anode ( $1.4 \mathrm{~cm} \times 0.8 \mathrm{~cm} \times 0.2 \mathrm{~cm}$ submerged), platinum plated cathode (1.4 cm $\times 0.8 \mathrm{~cm} \times 0.2 \mathrm{~cm}$ submerged), constant current of $5 \mathrm{~mA}$ or constant potential of $5 \mathrm{~V}$ between the electrodes, $5(0.2 \mathrm{mmol}), \mathrm{MgBr}_{2}(0.2 \mathrm{mmol})$, $\mathrm{CH}_{3} \mathrm{CN} / \mathrm{H}_{2} \mathrm{O}(4 \mathrm{~mL} / 1 \mathrm{~mL})$, room temperature; $b$ ) isolated yields are indicated (dr > 95:5); c) constant potential of $3.5 \mathrm{~V}$ at the anode vs a $\mathrm{Ag} / \mathrm{AgCl}(3 \mathrm{M}$ aq. $\mathrm{KCl}$ ) ref electrode; d) $\mathrm{MgCl}_{2}$ was used instead of $\mathrm{MgBr}_{2} ; \mathrm{d}$ ) constant cell potential of $8 \mathrm{~V}$.

We were then eager to demonstrate the synthetic utility of the products obtained by this electrochemical halocyclization (Scheme 5). Indeed, it is well known that the bromide atom of 3a-bromoindolines such as 8 could be substituted by various functional groups. ${ }^{1,2}$ Therefore, allylfuranoindoline 9 was obtained by treating 3a-bromofuranoindoline 7c with allylsilane and AgOTf. ${ }^{1 \mathrm{~g}}$ As described by $\mathrm{Ye}$, exo-3a-bromopyrroloindoline 80 obtained from D-tryptophan could be converted by the addition of indole in presence of $t$-BuOK and triethylborane into endo-3a-indolyl-pyrroloindoline $\mathbf{1 0}$ which is an intermediate of the synthesis of gliocladins B and C. ${ }^{21}$

Application of the electrochemical bromocyclization to (L)tryptophan-derived diketopiperazine $\mathbf{1 1}$ with 2 equivalents of $\mathrm{MgBr}_{2}$ resulted in a double bromo-cyclisation to yield exo-endo compound 12 and endo-endo compound 13 which were respectively converted by Tokuyama into (-)-epi-amauromine and (+)-novoamauromine. ${ }^{2 m}$ This procedure is competitive with the use of NBS by Tokuyama which required to perform 2 steps the double bromocyclisation. ${ }^{2 m}$ 
Scheme 4. Electrochemical dearomative bromocyclization of tryptamine and tryptophan derivatives.

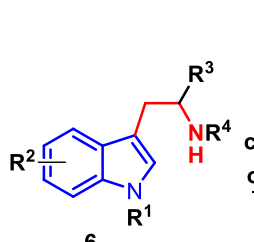

$$
\mathrm{C}(+) \overbrace{\text { undivided cell }} \mathrm{Pt}(-)
$$

\section{constant current $4.5 \mathrm{~mA} / \mathrm{cm}^{2}$} or constant cell potential $5 \mathrm{~V}$

$\mathrm{MgBr}_{2}$ (1.0 equiv.)

$\mathrm{CH}_{3} \mathrm{CN} / \mathrm{H}_{2} \mathrm{O}(4: 1), \mathrm{rt}^{\mathrm{a}, \mathrm{b}}$
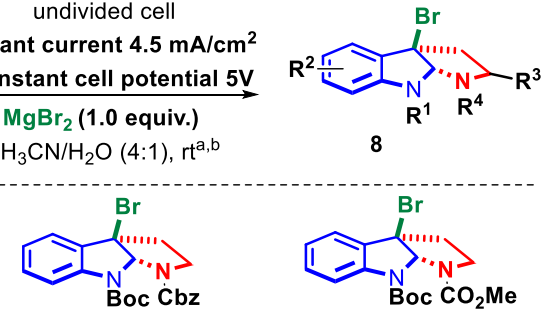

8 b, $70 \%\left(4.5 \mathrm{~mA} / \mathrm{cm}^{2}\right)$ $63 \%(5 \mathrm{~V})$

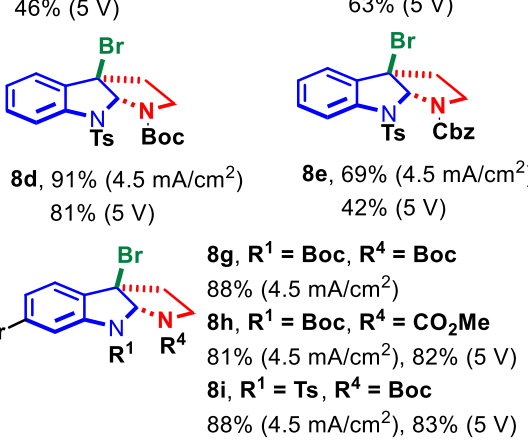

8 e, $69 \%\left(4.5 \mathrm{~mA} / \mathrm{cm}^{2}\right)$ $42 \%(5 \mathrm{~V})$ $81 \%(5 \mathrm{~V})$

$8 \mathrm{~g}, \mathbf{R}^{1}=$ Boc, $\mathbf{R}^{4}=$ Boc

$88 \%\left(4.5 \mathrm{~mA} / \mathrm{cm}^{2}\right)$
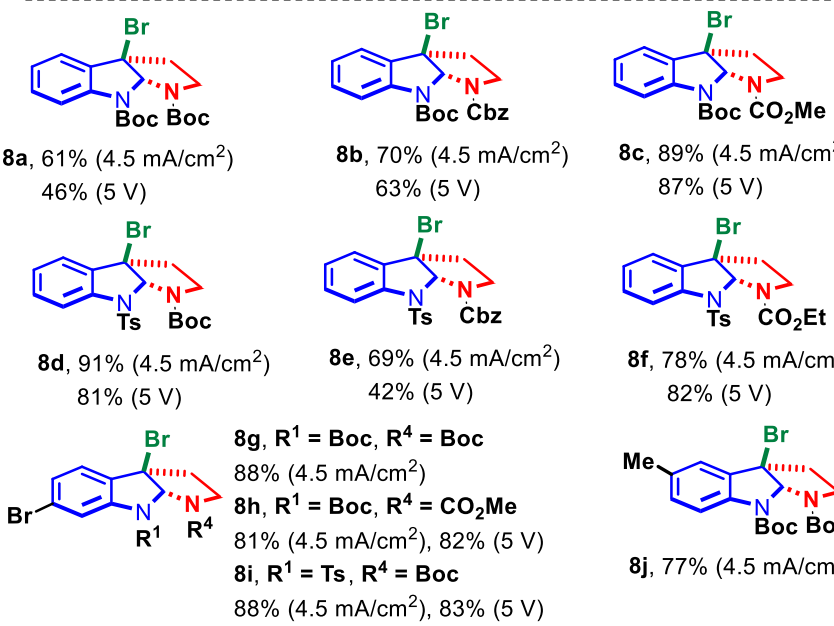

$8 c, 89 \%\left(4.5 \mathrm{~mA} / \mathrm{cm}^{2}\right)$ $87 \%(5 \mathrm{~V})$
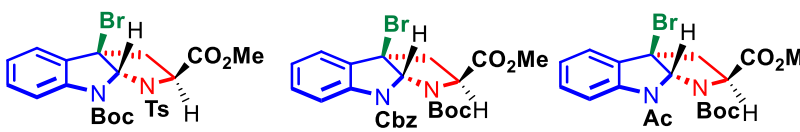

8 k, $91 \%(90: 10)$ $\left(4.5 \mathrm{~mA} / \mathrm{cm}^{2}\right)^{\mathrm{c}}$ $87 \%(90: 10)(5 \mathrm{~V})^{\mathrm{C}}$

8I, $69 \%(90: 10)$ $72 \%(90: 10)(5 \mathrm{~V})$

$8 \mathrm{~m}, 94 \%(90: 10)$ $\left(4.5 \mathrm{~mA} / \mathrm{cm}^{2}\right)$ $96 \%(90: 10)(5 \mathrm{~V})$

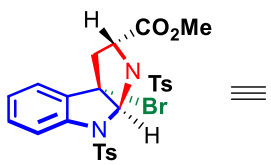

8 n, $51 \%(95: 5)$

$\left(4.5 \mathrm{~mA} / \mathrm{cm}^{2}\right)^{\mathrm{c}}$

$55 \%(95: 5)(5 \mathrm{~V})^{\mathrm{c}}$

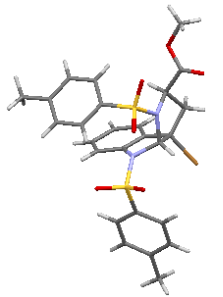

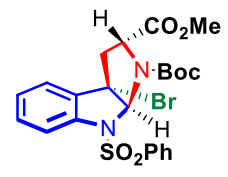

$80,81 \%(95: 5)$

$\left(1.8 \mathrm{~mA} / \mathrm{cm}^{2}\right)^{\mathrm{d}}$ $84 \%(95: 5)(5 \mathrm{~V})^{\mathrm{d}}$

$X$-ray crystal structure of 8

a) Undivided cell, graphite-SK50 anode $(1.4 \mathrm{~cm} \times 0.8 \mathrm{~cm} \times 0.2 \mathrm{~cm}$ submerged), platinum plated cathode (1.4 cm $\times 0.8 \mathrm{~cm} \times 0.2 \mathrm{~cm}$ submerged), constant current of $5 \mathrm{~mA}$ or constant potential of $5 \mathrm{~V}$ between the electrodes, $6(0.2 \mathrm{mmol}), \mathrm{MgBr}_{2}(0.2 \mathrm{mmol})$, $\mathrm{CH}_{3} \mathrm{CN} / \mathrm{H}_{2} \mathrm{O}(4 \mathrm{~mL} / 1 \mathrm{~mL})$, room temperature; $b$ ) isolated yields are indicated ( $d r>95: 5$ unless otherwise noted in parenthesis); c) on $0.1 \mathrm{mmol}$ of 6 and $\mathrm{MgBr}_{2}$ in $\mathrm{CH}_{3} \mathrm{CN} / \mathrm{H}_{2} \mathrm{O}$ (4 $\mathrm{mL} / 1 \mathrm{~mL})$; d) on $0.6 \mathrm{mmol}$ of 6 and $\mathrm{MgBr}_{2}(0.6 \mathrm{mmol})$ in $\mathrm{CH}_{3} \mathrm{CN} / \mathrm{H}_{2} \mathrm{O}(12 \mathrm{~mL} / 3 \mathrm{~mL})$, anode (3.4 $\mathrm{cm} \times 0.8 \mathrm{~cm} \times 0.2 \mathrm{~cm}$ submerged), cathode ( $3.4 \mathrm{~cm} \times 0.8 \mathrm{~cm} \times 0.2 \mathrm{~cm}$ submerged).

Cyclic voltammetry (CV, see $\mathrm{SI}$ ) of the reactants in acetonitrile and water showed oxidation of $\mathrm{MgBr}_{2}$ at a lower potential than NTs-tryptophol 7a. The oxidation peak observed (1.3 $\vee$ vs SCE) during the $\mathrm{CV}$ of $\mathrm{MgBr}_{2}$ seems to correspond to the formation of $\mathrm{Br}_{2} \cdot{ }^{11 \mathrm{j}, 13}$ In presence of $\mathrm{N}-\mathrm{Ts}$ tryptophol $7 \mathrm{a}$, a net increase of the intensity of this oxidation wave is observed. This observation might be in favour of the oxidation of $\mathrm{MgBr}_{2}$ at the anode into an electrophilic bromine reagent that would react with the $\mathrm{C} 2=\mathrm{C} 3$ bond of indoles to form the bromonium bridge C (Scheme 1). ${ }^{14}$

Scheme 5. Synthetic applications.
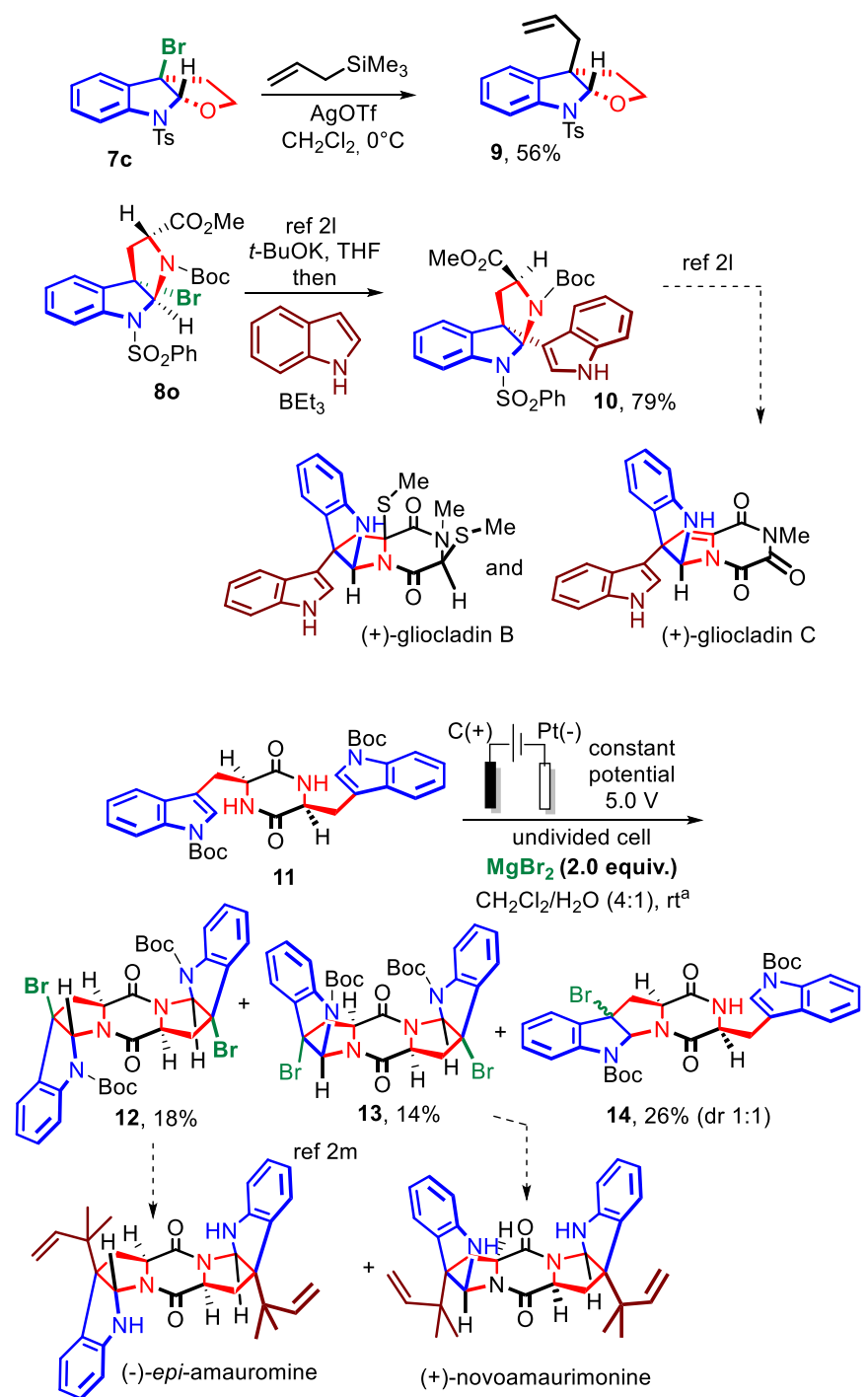

a) Undivided cell, graphite-SK50 anode $(1.4 \mathrm{~cm} \times 0.8 \mathrm{~cm} \times 0.2 \mathrm{~cm}$ submerged), platinum plated cathode $(1.4 \mathrm{~cm} \times 0.8 \mathrm{~cm} \times 0.2 \mathrm{~cm}$ submerged), constant potential of $5 \mathrm{~V}$ between the electrodes, 1 (0.1 mmol), $\mathrm{MgBr}_{2}(0.2 \mathrm{mmol}), \mathrm{CH}_{2} \mathrm{Cl}_{2} / \mathrm{H}_{2} \mathrm{O}(4 \mathrm{~mL} / 1 \mathrm{~mL})$, room temperature.

\section{Conclusion}

In conclusion we developed a general electrochemical bromocyclization of tryptophol, tryptamine and tryptophan derivatives via the anodic oxidation of $\mathrm{MgBr}_{2}$ into an electrophilic bromine reagent which could oxidized the indole nucleus into bromofuranoindolines and bromopyranoindolines. This protocol avoids the use of an additional electrolyte and of an external oxidant.

\section{Conflicts of interest}

"There are no conflicts to declare".

\section{Acknowledgment}


We thank Mrs Sakna Bazzi and Dr. Mohamed Mellah (ICMMO, Univ. Paris Sud) for their assistance in the recording of the CV. JW thanks the China Scholarship Council (CSC) for his PhD fellowship. We also gratefully acknowledge the ANR (ANR-17CE07-0050; "ArDCo"), the Université Paris Sud and the CNRS for financial support.

\section{Notes and references}

¥ Electrochemical reactions were performed with ElectraSyn 2.0 package (IKA). CCDC 1910836 (8n) contains the supplementary crystallographic data for this paper.

1 (a) M. Bruncko, D. Crich and R. Samy, J. Org. Chem., 1994, 59 5543-5549; (b) M. Somei, T. Iwaki, F. Yamada and S. Funaki, Heterocycles, 2005, 65, 1811-1815; (c) J. A. González-Vera, M. T. García-López and R. Herranz, J. Org. Chem., 2007, 72, 53955398; (d) V. R. Espejo and J. D. Rainier, J. Am. Chem. Soc., 2008, 130, 12894-12895; (e) I. Villanueva-Margalef, D. E. Thurston and G. Zinzalla, Org. Biomol. Chem., 2010, 8, 5294-5303; (f) V. R. Espejo, X.-B. Li and J. D. Rainier, J. Am. Chem. Soc., 2010, 132, 8282-8284. (g) Y. Wang, C. Kong, Y. Du, H. Song, D. Zhang and Y. Qin, Org. Biomol. Chem., 2012, 10, 2793-2797.

2 (a) M. Movassaghi and M. A. Schmidt, Angew. Chem. Int. Ed. 2007, 46, 3725-3728; (b) M. Movassaghi, M. A. Schmidt and J. A. Ashenhurst, Angew. Chem. Int. Ed., 2008, 47, 1485-1487; (c) Pérez-Balado and Á. R. de Lera, Org. Lett., 2008, 10, 37013704; (d) J. Kim, J. A. Ashenhurst and M. Movassaghi, Science, 2009, 324, 238-241; (e) V. R. Espejo and J. D. Rainier, Org. Lett., 2010, 12, 2154-2157; (f) L. Furst, J. M. R. Narayanam and C. R. J. Stephenson, Angew. Chem. Int. Ed., 2011, 50, 96559659; (g) J. Kim and M. Movassaghi, J. Am. Chem. Soc., 2011 133, 14940-14943; (h) M. Wang, X. Feng, L. Cai, Z. Xu and T. Ye, Chem. Commun., 2012, 48, 4344-4346; (i) N. Boyer and M. Movassaghi, Chem. Sci., 2012, 3, 1798-1803; (j) Y. Sun, R. Li, W. Zhang and A. Li, Angew. Chem. Int. Ed., 2013, 52, 92019204; (k) W. Xie, G. Jiang, H. Liu, J. Hu, X. Pan, H. Zhang, X Wan, Y. Lai and D. Ma, Angew. Chem. Int. Ed., 2013, 52, 12924-12927; (I) H. Lei, L. Wang, Z. Xu and T. Ye, Org. Lett., 2017, 19, 5134-5137; (m) H. Hakamata, S. Sato, H. Ueda and H. Tokuyama, Org. Lett., 2017, 19, 5308-5311; for a synthetic study towards diazonamide $A$ and azonazine from us: $N$. Denizot, R. Guillot, C. Kouklovsky and G. Vincent, Chem. - Eur. J., 2015, 21, 18953-18956.

3 D. Tu, L. Ma, X. Tong, X. Deng and C. Xia, Org. Lett., 2012, 14 4830-4833.

4 J. Xu and R. Tong, Green Chem., 2017, 19, 2952-2956.

5 For reviews: (a) 1 R. Francke and R. D. Little, Chem. Soc. Rev., 2014, 43, 2492-2521; (b) E. J. Horn, B. R. Rosen and P. S. Baran, ACS Cent. Sci., 2016, 2, 302-308; (c) R. Feng, J. A. Smith and K. D. Moeller, Acc. Chem. Res., 2017, 50, 2346-2352; (d) M. Yan, Y. Kawamata and P. S. Baran, Chem. Rev., 2017, 117, 13230-13319; (e) A. Wiebe, T. Gieshoff, S. Möhle, E. Rodrigo, M. Zirbes and S. R. Waldvogel, Angew. Chem. Int. Ed., 2018, 57, 5594-5619; (f) S. Möhle, M. Zirbes, E. Rodrigo, T. Gieshoff, A. Wiebe and S. R. Waldvogel, Angew. Chem. Int. Ed., 2018, 57, 6018-6041; (g) Y. Jiang, K. Xu and C. Zeng, Chem. Rev. 2018, 118, 4485-4540; (h) G. S. Sauer and S. Lin, ACS Catal., 2018, 8, 5175-5187; (i) G. M. Martins, B. Shirinfar, T. Hardwick and N. Ahmed, ChemElectroChem, 2019, 6, 1254-1254; for selected examples of electrochemical intramolecular C-O/C-N bond formation: (k) S. Zhang, L. Li, J. Zhang, J. Zhang, M. Xue and K. Xu, Chem. Sci., 2019, 10, 3181-3185; (I) J. D. Haupt, M. Berger and S. R. Waldvogel, Org. Lett., 2019, 21, 242-245; (m) H. Wang, J. Shi, J. Tan, W. Xu, S. Zhang and K. Xu, Org. Lett., 2019, 21, 9430-9433.
6 For a recent review on electrochemical dearomatizations: $S$. Lv, G. Zhang, J. Chen and W. Gao, Adv. Synth. Catal., DOI:10.1002/adsc.201900750.

7 (a) N. T. Nguyen, M. Z. Wrona and G. Dryhurst, J. Electroanal. Chem. Interfacial Electrochem., 1986, 199, 101-126; (b) J. Royer, L. Planas, T. Martens and F. Billon-Souquet, Heterocycles, 2004, 63, 765; (c) B. Yin, L. Wang, S. Inagi and T. Fuchigami, Tetrahedron, 2010, 66, 6820-6825; (d) H. Ding, P. L. DeRoy, C. Perreault, A. Larivée, A. Siddiqui, C. G. Caldwell, S. Harran and P. G. Harran, Angew. Chem. Int. Ed., 2015, 54, 4818-4822; (e) K. Liu, S. Tang, P. Huang and A. Lei, Nat. Commun., 2017, 8, 775; (f) N. Fu, G. S. Sauer, A. Saha, A. Loo and S. Lin, Science, 2017, 357, 575-579: (g) L. Li and S. Luo, Org. Lett., 2018, 20, 1324-1327; (h) S. Zhang, L. Li, P. Wu, P. Gong, R. Liu and K. Xu, Adv. Synth. Catal., 2019, 361, 485-489.

8 For reviews on indole dearomatization: (a) S. P. Roche, J.-J. Youte Tendoung and B. Tréguier, Tetrahedron, 2015, 71, 3549-3591; (b) N. Denizot, T. Tomakinian, R. Beaud, C. Kouklovsky and G. Vincent, Tetrahedron Lett., 2015, 56, 44134429.

9 (a) R. Beaud, R. Guillot, C. Kouklovsky and G. Vincent, Angew. Chem. Int. Ed., 2012, 51, 12546-12550; (b) T. Tomakinian, R. Guillot, C. Kouklovsky and G. Vincent, Angew. Chem. Int. Ed., 2014, 53, 11881-11885; (c) D. Lachkar, N. Denizot, G. Bernadat, K. Ahamada, M. A. Beniddir, V. Dumontet, J.-F. Gallard, R. Guillot, K. Leblanc, E. O. N'nang, V. Turpin, C. Kouklovsky, E. Poupon, L. Evanno and G. Vincent, Nat. Chem., 2017, 9, 793-798; (d) D. Ryzhakov, M. Jarret, R. Guillot, C. Kouklovsky and G. Vincent, Org. Lett., 2017, 19, 6336-6339; (e) J. Wu, R. K. Nandi, R. Guillot, C. Kouklovsky and G. Vincent, Org. Lett., 2018, 20, 1845-1848; (f) D. Ryzhakov, M. Jarret, R. Guillot, C. Kouklovsky and G. Vincent, Org. Lett., 2019, 21, 4986-4990.

10 J. Wu, Y. Dou, R. Guillot, C. Kouklovsky and G. Vincent, J. Am. Chem. Soc., 2019, 141, 2832-2837.

11 For recent examples: (a) N. Fu, G. S. Sauer and S. Lin, J. Am. Chem. Soc., 2017, 139, 15548-15553; (b) K.-Y. Ye, G. Pombar, N. Fu, G. S. Sauer, I. Keresztes and S. Lin, J. Am. Chem. Soc. 2018, 140, 2438-2441; (c) Y. Yuan, A. Yao, Y. Zheng, M. Gao, Z. Zhou, J. Qiao, J. Hu, B. Ye, J. Zhao, H. Wen and A. Lei, iScience, 2019, 12, 293-303; (d) Q.-L. Yang, X.-Y. Wang, T.-L. Wang, X. Yang, D. Liu, X. Tong, X.-Y. Wu and T.-S. Mei, Org. Lett., 2019, 21, 2645-2649; (e) X. Sun, H.-X. Ma, T.-S. Mei, P. Fang and Y. Hu, Org. Lett., 2019, 21, 3167-3171; (f) K. Yamamoto, K. Ishimaru, S. Mizuta, D. Minato, M. Kuriyama and O. Onomura, Synlett, 2019, 30, 1204-1208; (g) W. Xie, S. Ning, N. Liu, Y. Bai, S. Wang, S. Wang, L. Shi, X. Che and J. Xiang, Synlett, 2019, 30, 1313-1316; (h) C. Chen, J.-C. Kang, C. Mao, J.-W. Dong, Y.-Y. Xie, T.-M. Ding, Y.-Q. Tu, Z.-M. Chen and S.-Y. Zhang, Green Chem., 2019, 21, 4014-4019; (i) B. D. W. Allen, M. D. Hareram, A. C. Seastram, T. McBride, T. Wirth, D. L. Browne and L. C. Morrill, Org. Lett., 2019, 21, 9241-9246; see also (j) F. Billon-Souquet, T. Martens and J. Royer, Tetrahedron, 1996, 52, 15127-15136.

12 (a) L. Sun, X. Zhang, Z. Li, J. Ma, Z. Zeng and H. Jiang, Eur. J. Org. Chem., 2018, 4949-4952; (b) L. Sun, X. Zhang, C. Wang, H. Teng, J. Ma, Z. Li, H. Chen and H. Jiang, Green Chem., 2019, 21, 2732-2738; (c) P. Zhang, J. Chen, W. Gao, Y. Xiao, C. Liu, S. Xu, X. Yan and D. Qin, Molecules, 2019, 24, 696/

$13 \mathrm{Yu}, \mathrm{X}$. Jin and G. Z. Chen, J. Electroanal. Chem., 2013, 688, 371378.

14 In the potentiostatic mode, the difference of potential between the two electrodes may seem high and it could be argue that both bromide ions and the indole nucleus of $\mathbf{6}$ or $\mathbf{7}$ could be oxidized simultaneously. However, this high difference of potential may be attributed to the high resistance of the reaction mixture. 